Indexed by

\section{Scopus}

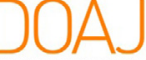

DIRECTORY OF OPEN ACCES

JOURNALS

Crossref

KOBSON

Muhannd Waleed Majeed

Mustansiriyah University,

College of Engineering, Water

Resources Engineering De-

partment, Baghdad, Iraq
Lubna Mohammed Abd

Mustansiriyah University,

College of Engineering, Environmental Engineering Department, Baghdad, Iraq

\section{Aamer Najim Abbas}

Mustansiriyah University, College of Engineering, Water Resources Engineering Department, Baghdad, Iraq

Key words: freshwater, waste water, hospital, sewer, ultimate load, first crack, failure pattern, deflection

doi:10.5937/jaes0-30049

Cite article:

Majeed, M. W., Abd, L. M., Abbas, A. N. (2021) EFFECT OF CURING BY DIFFERENT POLLUTED WATER ON THE STRUCTURAL BEHAVIOR OF RC SLABS, Journal of Applied Engineering Science, 19(3), 833-840, DOI:10.5937/jaes0-30049

Online aceess of full paper is available at: www.engineeringscience.rs/browse-issues 


\title{
EFFECT OF CURING BY DIFFERENT POLLUTED WATER ON THE STRUCTURAL BEHAVIOR OF RC SLABS
}

\author{
Muhannd Waleed Majeed', Lubna Mohammed Abd" ${ }^{2 *}$, Aamer Najim Abbas ${ }^{1}$ \\ ${ }^{1}$ Mustansiriyah University, College of Engineering, Water Resources Engineering Department, Baghdad, Iraq \\ ${ }^{2}$ Mustansiriyah University, College of Engineering, Environmental Engineering Department, Baghdad, Iraq
}

There was a serious water problem especially in the region close to the sewer treatment plants. Therefore, an effort has been made to utilize the waste water from the sewer treatment plants for building purposes, so that the water problem can be greatly minimized and the waste water can be properly disposed of for good environmental conservation. Slabs in severe curing conditions performed by hospital waste water and sewer waste water.. This article highlights an experimental analysis on the behavior of concrete foundations in severe curing conditions performed by hospital waste water and sewer waste water. The experiment measured ultimate load, first crack load, load-deflection behavior, stiffness and evaluated the crack pattern of twelve reinforced concrete slabs after curing the specimens for 28 days. The results of the test indicate that the use of hospital and sewer waste water could reduce the strength, stiffness and accelerate damage of tested slabs. Mechanical properties such as compressive strength, elastic modulus, flexural strength, etc. were examined by pouring various concrete samples in the element of cubes, cylinders and prisms, etc. and were concluded to be acceptable.

Key words: freshwater, waste water, hospital, sewer, ultimate load, first crack, failure pattern, deflection

\section{INTRODUCTION}

Reinforced concrete is a composite material consisting of reinforcing bars made of steel embedded in a concrete volume[1]. Reinforcement bars carry the largest portion of the tensile load as well as provide a degree of cracks strengthening to a concrete that is itself compressed [2]. Corrosion of steel bars in concrete is a major universal problem. As a result of corrosion damage, the serviceability and structural integrity of reinforced concrete can be substantially reduced. Whenever the reinforcement bar is inserted into concrete corrodes, its volume increases with corrosion products [3]. Both the iron oxide and the hydroxide forms have common volumes greater than those of steel. The expansive forces produced by the corrosion of steel cause the tensile crack of concrete. This in turn produces a decline in concrete's serviceability and structural integrity, besides affecting its aesthetics [4]. A local degradation of the passive film on the steel by the chloride ions, and complete loss of passivity by concrete neutralization according to the atmospheric $\mathrm{CO} 2$ effect, are the two main factors of corrosion reinforcing bar [5]. The following are the main factors that cause corrosion of the reinforcement bar in concrete.

1. Reduction in alkalinity because of chlorine [6].

2. Concrete cracks due to mechanical pressure [7].

3. Corrosion of steel rebar due to environmental pollution [7].

4. If the surface of the concrete is subject to long- term wetting due to accumulation of water [8].

5. High water- cement ratio may be a cause the corrosion of reinforcing steels [9].
Several methods are used to reduce and prevent corrosion of reinforcement steel bars in concrete. Some are related to the manufacture of concrete, whereas others are related to a quality, composition and coating of steel used for the manufacture of bar reinforcement, normally the choice is made based on cost [12]. The coatings used on the reinforcement bars are i) hot dip galvanizing [13], ii) fused epoxy coating [14] and iii) stainless steel coating [15]. Reinforcing bars of stainless steel are often used. Special composition of steel reinforcement bars to prevent corrosion was also attempted. Many steel plants in world have experimented with the different weathering steel compositions. Indeed some producers in world have tried very aggressively marketing these reinforcement steel plates. But after extensive in- house and academic research, it was found that when buried, weathering steels consistently have poor performance. Then all the reputed steel makers abroad suspended the manufacture of such steel bars for reinforcements.

\section{MATERIALS PROPERTIES AND TESTING PROCEDURES}

\section{Experimental program}

A total of twelve two-way RC slabs with dimensions of $500 \times 500 \times 50 \mathrm{~mm}$ were prepared and experimentally tested within the context of the research program. The research plan included casting concrete slabs with two types; normal strength concrete and high strength concrete.

The mix proportion was $(1: 2: 3)$ by weight for cement, sand, gravel respectively with water to cement content of 0.4 for normal strength concrete while there was 
$(1: 1.5: 2)$ by weight for cement, sand, gravel respectively with $\mathrm{w} / \mathrm{c}$ ratio of 0.35 foe high strength con crete.

These slabs were cured with three types of water; drinking water, hospital waste water, and sewage waste water for 28 days and 56 days.

The type of cement used to manufacture the concrete was Ordinary Portland Cement Type-I, and the maximum aggregate size was $10 \mathrm{~mm}$. Production of the slabs was achieved by using rotary mixer in two classes at separate times. On the day of testing the slabs, the average compressive strength measured on cubes with dimensions of $150 \times 150 \times 150 \mathrm{~mm}$ (average results of three specimens). The $6 \mathrm{~mm}$ deformed steel bars had a yield stress of 470 $\mathrm{MPa}$, a tensile strength of $508 \mathrm{MPa}$, and a 7.2 percent ultimate strain (average of three specimens).

All slabs were reinforced in the same ratio and for both directions in the bottom side of a section exposed to tension, deformed reinforcing steel bars of diameter of $6 \mathrm{~mm}$ with a distance of $70 \mathrm{~mm}$ was distributed in both directions, as shown in Figure (1).

\section{Test setting}

All specimens experienced static point loading and were supported at their perimeter as simply supported. The load was transferred in the slab center at a displacement rate of $1 \mathrm{~mm} / \mathrm{min}$ using a hydraulic test machine with a capacity of $2000 \mathrm{kN}$, which was mounted on a rigid steel frame.
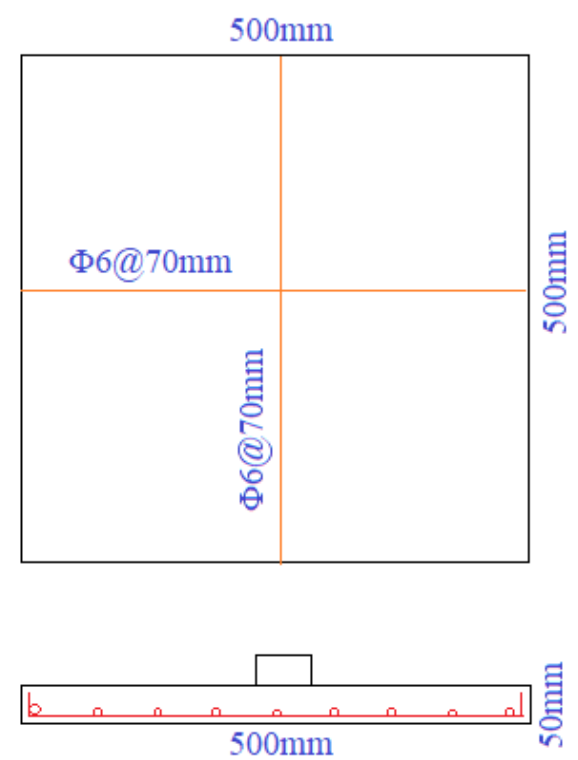

Figure 1: Reinforced concrete slab details

\section{Mechanical properties of concrete}

The concrete's compressive strength was evaluated by testing and pouring 36 cubes, 18 cubic models were poured for each type of concrete; nine cubes were cured for 28 days with three cubes for each type of water and nine other cubes were cured for 56 days with three cubes for each type of water. To determine the modulus of elasticity of different concrete types in different cur-

Table 1: Mechanical properties of concrete

\begin{tabular}{|c|c|c|c|c|}
\hline $\begin{array}{l}\text { Specimen } \\
\text { configuration }\end{array}$ & Description & $\begin{array}{l}\text { Compressive } \\
\text { strength (MPa) }\end{array}$ & $\begin{array}{c}\text { Modulus of } \\
\text { elasticity (GPa) }\end{array}$ & $\begin{array}{l}\text { Modulus of } \\
\text { rupture (MPa) }\end{array}$ \\
\hline ND-28 & $\begin{array}{l}\text { Normal concrete, curing with fresh water at } \\
28 \text { days }\end{array}$ & 27.8 & 28.15 & 4.21 \\
\hline $\mathrm{NH}-28$ & $\begin{array}{l}\text { Normal concrete, curing with hospital waste } \\
\text { water at } 28 \text { days }\end{array}$ & 22.3 & 24.31 & 3.83 \\
\hline NW-28 & $\begin{array}{l}\text { Normal concrete, curing with waste water at } \\
28 \text { days }\end{array}$ & 24.8 & 25.22 & 3.94 \\
\hline ND-56 & $\begin{array}{l}\text { Normal concrete, curing with fresh water at } \\
56 \text { days }\end{array}$ & 32.11 & 30.93 & 5.15 \\
\hline $\mathrm{NH}-56$ & $\begin{array}{l}\text { Normal concrete, curing with hospital waste } \\
\text { water at } 56 \text { days }\end{array}$ & 25.37 & 26.31 & 4.23 \\
\hline NW-56 & $\begin{array}{l}\text { Normal concrete, curing with waste water at } \\
56 \text { days }\end{array}$ & 27.30 & 28.22 & 4.64 \\
\hline HD-28 & $\begin{array}{l}\text { High strength concrete, curing with fresh } \\
\text { water at } 28 \text { days }\end{array}$ & 72.98 & 121.78 & 7.28 \\
\hline $\mathrm{HH}-28$ & $\begin{array}{l}\text { High strength concrete, curing with hospital } \\
\text { waste water at } 28 \text { days }\end{array}$ & 63.44 & 103.53 & 6.19 \\
\hline HW-28 & $\begin{array}{l}\text { High strength concrete, curing with waste } \\
\text { water at } 28 \text { days }\end{array}$ & 65.71 & 109.78 & 6.59 \\
\hline HD-56 & $\begin{array}{l}\text { High strength concrete, curing with fresh } \\
\text { water at } 56 \text { days }\end{array}$ & 78.48 & 136.83 & 8.14 \\
\hline HН-56 & $\begin{array}{l}\text { High strength concrete, curing with hospital } \\
\text { waste water at } 56 \text { days }\end{array}$ & 69.75 & 111.65 & 7.22 \\
\hline HW-56 & $\begin{array}{l}\text { High strength concrete, curing with waste } \\
\text { water at } 56 \text { days }\end{array}$ & 71.22 & 115.94 & 7.42 \\
\hline
\end{tabular}


ing conditions, 36 cylinders were tested prior to the test of each slab (normal concrete; of age 28 days and 56 days, and high strength concrete; of age 28 days and 56 days); three specimens were cured in each water type. Similarly, the modulus of rupture of concretes used in this investigation was evaluated by the same specimen's number. The concrete compressive strength, modulus of elasticity and modulus of rupture are shown in Table (1).

\section{Waste water components}

The components of the sewage are composed of organic and inorganic materials; organic materials consist of $40 \%$ nitrogenous materials, 50\% carbohydrates; $10 \%$ fatty substances. As for inorganic materials they are: chlorides; nitrogen, phosphates, potassium oxide and some mineral salts; It contains a large and varied number of bacteria, which ranges between (125_150) billion cells / person / day in winter.

A set of physical and chemical tests are performed on hospital waste water according to internationally standard methods. The results shown in Table (2) indicate that the components of tested hospital waste water.

\section{RESULTS AND DISCUSSIONS}

\section{Ultimate load}

The primary objective of this research is to evaluate the ultimate load capacity of the slabs with reinforcing steel bars. And, in order to contrast the ultimate load capacity of these slabs with different environmental attack conditions. The ultimate load of slabs was recorded as shown in Table (3). Test result show that the ultimate load of the slabs cured with 28 days in freshwater (ND-28), hospital waste water $(\mathrm{NH}-28)$ and sewer waste water (NW-28), are $25.5 \mathrm{kN}, 22 \mathrm{kN}$ and $22.5 \mathrm{kN}$ respectively. The ultimate load capacity of specimens (NH-28) and (NW-28) decreased by $13.73 \%$ and $11.76 \%$ respectively, as compared with the reference specimen (ND-28).

The ultimate load of slabs tested at 56 days at same environmental conditions was listed in Table (3). The test results indicate that the specimens cured with hospital

Table 2: Components of hospital waste water

\begin{tabular}{|c|c|}
\hline Components & Quantity $(\mathrm{mg} / \mathrm{L})$ \\
\hline PO4 & 8.75 \\
\hline SO4 & 246.8 \\
\hline NO3 & 14.53 \\
\hline Cd & 0.13 \\
\hline Cr & 0.163 \\
\hline Fe & 1.035 \\
\hline B.O.D & 102.0 \\
\hline C.O.D & 213.5 \\
\hline T.S.S & 191.7 \\
\hline T.D.S & 1288 \\
\hline
\end{tabular}

waste water and sewer waste water show decreasing in ultimate load capacity about $19.12 \%$ and $11.76 \%$ respectively in comparison to the reference specimen.

The ultimate load of the slabs specimens was more affected by increasing of concrete strength. In case of 28 days curing with high compressive strength, the ultimate loads decreased from 44 to $35 \mathrm{kN}$ when cured with the fresh water and hospital waste water respectively, the specimen cured with sewer waste water the ultimate load between them. And the ultimate load capacity was decreased about $20.45 \%$ and $9.10 \%$ when specimen were cured with hospital waste water and with sewer waste water respectively as compared with the fresh water, while for 56 days of curing the ultimate load capacity was decreased about $16.36 \%$ and $13.63 \%$ when specimen were cured with hospital waste water and with sewer waste water respectively as compared with fresh water.

The reason for the decreasing in the resistance of the specimens as a result of curing with polluted water can be attributed to that, the entry of salts into the pores of the concrete and its crystallization inside it causes the external parts of the concrete to gradually deteriorate. The degree of influence of these factors on the concrete varies with the permeability of the concrete, as the higher the permeability, the greater the effect of the previous factors. The concrete corrodes as a result of the chemical reaction that occurs between soluble Sulphates with cement, which leads to weakening of its durability, cracked and fragmented.

\section{Yielding Load}

As indicated in Table (4), the yielding load of tested specimen cured by freshwater was higher than other specimens cured with hospital waste water and sewer waste water. In the normal strength concrete specimens cured with 28 days, the percentage of yielding load decrease about $16.67 \%$ and $10 \%$ when hospital waste water had been used respectively, as compared with the reference

Table 3: Ultimate load of tested slabs

\begin{tabular}{|c|c|c|}
\hline $\begin{array}{c}\text { Specimen } \\
\text { configuration }\end{array}$ & $\begin{array}{c}\text { Ultimate coad } \\
(\mathrm{kN})\end{array}$ & $\begin{array}{c}\text { Reduction in } \\
\text { ultimate load }(\%)\end{array}$ \\
\hline $\mathrm{ND}-28$ & 25.5 & $\mathrm{R}^{*}$ \\
\hline $\mathrm{NH}-28$ & 22 & 13.73 \\
\hline $\mathrm{NW}-28$ & 22.5 & 11.76 \\
\hline $\mathrm{ND}-56$ & 34 & $\mathrm{R}^{*}$ \\
\hline $\mathrm{NH}-56$ & 27.5 & 19.12 \\
\hline $\mathrm{NW}-56$ & 30 & 11.76 \\
\hline $\mathrm{HD}-28$ & 44 & $\mathrm{R}^{*}$ \\
\hline $\mathrm{HH}-28$ & 35 & 20.45 \\
\hline $\mathrm{HW}-28$ & 40 & 9.10 \\
\hline $\mathrm{HD}-56$ & 55 & $\mathrm{R}^{*}$ \\
\hline $\mathrm{HH}-56$ & 46 & 16.36 \\
\hline HW-56 & 47.5 & 13.63 \\
\hline${ }^{*}$ Reference specimens & \\
\hline
\end{tabular}


specimen, while for other specimens cured with 56 day the percentage of yielding load decrease about $20 \%$ and $12 \%$ when hospital waste water had been used respectively, as compared with the reference specimen. On the other hand, the high strength concrete specimens cured with 28 days, the percentage of yielding load decrease about $33.33 \%$ and $13.33 \%$ when hospital waste water had been used respectively, as compared with the reference specimen, while for other specimens cured with 56 day the percentage of yielding load decrease about $12.5 \%$ and $7.5 \%$ when hospital waste water had been used respectively, as compared with the reference specimen, so, it can be noted that high strength concrete specimens exhibited yielding loads higher than corresponding normal strength concrete specimens.

The chlorides ions attack the steel and cause corrosion very slowly, increasing with an increase in the presence of carbon dioxide. It may be conclude that concrete deformations increase with the presence of carbon dioxide or its oxides, but less than that caused by chlorides and dissolved salts in the components of the mixture. In the event that the chlorides ions touch the outer surface of the steel bars, additional negative effects may occur.

\section{First crack load}

Table (5) compares the first crack load of twelve slabs specimens. It can be seen from this Table that, the specimens cured with freshwater displayed slightly larger first crack loads. And it is interesting to note that the first crack of specimens cured with all types of water for 28 days ranged from $7.5 \mathrm{kN}$ in specimen cured with freshwater to $6.5 \mathrm{kN}$ in specimen cured with the hospital waste water, while the specimen cured with sewer waste water recorded first crack at $7 \mathrm{kN}$. The specimens with 56 days curing behaved in the same way. Specimen ND-56 (56 days of curing by freshwater) achieved first crack at $10 \mathrm{kN}$, but the specimens $\mathrm{NH}-56$ and NW-56 achieved first crack at $7 \mathrm{kN}$

Table 4: Yield load of tested slabs

\begin{tabular}{|c|c|c|}
\hline $\begin{array}{c}\text { Specimen } \\
\text { configuration }\end{array}$ & Yield load $(\mathrm{kN})$ & $\begin{array}{c}\text { Reduction in } \\
\text { yield Load }(\%)\end{array}$ \\
\hline ND-28 & 15 & $\mathrm{R}^{*}$ \\
\hline $\mathrm{NH}-28$ & 12.5 & 16.67 \\
\hline NW-28 & 13.5 & 10 \\
\hline $\mathrm{ND}-56$ & 25 & $\mathrm{R}^{*}$ \\
\hline $\mathrm{NH}-56$ & 20 & 20 \\
\hline $\mathrm{NW}-56$ & 22 & 12 \\
\hline $\mathrm{HD}-28$ & 30 & $\mathrm{R}^{*}$ \\
\hline $\mathrm{HH}-28$ & 20 & 33.33 \\
\hline $\mathrm{HW}-28$ & 26 & 13.33 \\
\hline HD-56 & 40 & $\mathrm{R}^{*}$ \\
\hline HH-56 & 35 & 12.5 \\
\hline HW-56 & 37 & 7.5 \\
\hline${ }^{*}$ Reference specimens & \\
\hline
\end{tabular}

and $7.5 \mathrm{kN}$ respectively. The immersion of slabs specimens with freshwater for longer period contributed to the increase first crack load, on the other hand, immersion the specimens in contaminated water didn't contribute to the delay in the appearance of cracks of the tested slabs.

For the high strength concrete slabs series with a concrete compressive strength, the polluted water help the specimens to resist cracks appearance because of the high density of concrete, which contributed to the difficulty seepage of the polluted materials into the concrete slab. It can be seen from Table (5) that the specimens cured with freshwater recorded first crack at 11.5 and $12.5 \mathrm{kN}$ for specimens HD-28 and HD-56 respectively. Specimens $\mathrm{HH}-28$ and $\mathrm{HH}-$ 56 achieved first crack loads at 7.5 and $12 \mathrm{kN}$ respectively. On the contrary, specimens HW-28 and HW-56 exhibited first crack loads at 10 and $12 \mathrm{kN}$ respectively.

\section{Load-deflection response}

Figures (2) to (5) relate the twelve specimens with Load and average deflection responses. Table (6) shows the loads and average deflections at first crack, first yield, and ultimate load, which describes the deflection at first crack load, yield load and failure load were achieved depending on the load-deformation curves, then the deflection was marked. The ultimate deflection for Specimens ND- 28, constructed with normal strength concrete and cured with freshwater, was approximately $2.3 \%$ and $11.35 \%$ lower than for specimens $\mathrm{NH}-28$ and NW-28, which were constructed with normal strength concrete and cured with hospital waste water and sewer waste water respectively. From Table (6), it can be seen that the first cracking deflection increased when curing with the hospital waste water and sewer waste water. The first crack deflections of specimens cured 28 days with the hospital waste water and sewer waste water for normal strength concrete slabs were $0.53 \mathrm{~mm}$ and $0.45 \mathrm{~mm}$ respectively, while deflection of specimen cured with fresh water was $0.35 \mathrm{~mm}$.

Table 5: First crack load of tested slabs

\begin{tabular}{|c|c|c|}
\hline $\begin{array}{c}\text { Specimen } \\
\text { configuration }\end{array}$ & $\begin{array}{c}\text { First crack load } \\
(\mathrm{kN})\end{array}$ & $\begin{array}{c}\text { Reduction in first } \\
\text { crack load }(\%)\end{array}$ \\
\hline $\mathrm{ND}-28$ & 7.5 & $\mathrm{R}^{*}$ \\
\hline $\mathrm{NH}-28$ & 6.5 & 13.33 \\
\hline $\mathrm{NW}-28$ & 7 & 6.67 \\
\hline $\mathrm{ND}-56$ & 10 & $\mathrm{R}^{*}$ \\
\hline $\mathrm{NH}-56$ & 7 & 30 \\
\hline $\mathrm{NW}-56$ & 7.5 & 25 \\
\hline $\mathrm{HD}-28$ & 11.5 & $\mathrm{R}^{*}$ \\
\hline $\mathrm{HH}-28$ & 7.5 & 34.78 \\
\hline $\mathrm{HW}-28$ & 10 & 13.04 \\
\hline $\mathrm{HD}-56$ & 12.5 & $\mathrm{R}^{*}$ \\
\hline $\mathrm{HH}-56$ & 12 & 4 \\
\hline $\mathrm{HW}-56$ & 12 & 4 \\
\hline${ }^{*}$ Reference specimens & \\
\hline
\end{tabular}


Also, the deflection at yielding load for specimens cured 28 days with the hospital waste water and sewer waste water for normal strength concrete slabs were $1.22 \mathrm{~mm}$ and $1.06 \mathrm{~mm}$ respectively, in the same way the specimen cured with fresh water recorded deflection at yielding load $1.01 \mathrm{~mm}$. The same behavior was observed when comparing the 56-day curing specimens in different types of water. As there is an increase in the deformation of the models as a result of their exposure to hospital and sewage water by $18 \%$ and $23.23 \%$ at the maximum load, and by the amount of 26.5 and 35.24 at the yield load, the same applies at the first crack load, as the specimens recorded an increase in deformations by $16.27 \%$ and $8.33 \%$.

For the high strength concrete slabs series with a concrete compressive strength, the polluted water cause the specimens to deflect in the same way of normal strength concrete slabs. It can be seen from Table (6), the specimens cured with freshwater recorded ultimate load deflections $3.21 \mathrm{~mm}$ and $2.89 \mathrm{~mm}$ for specimens HD-28 and HD-56 respectively. Specimens $\mathrm{HH}-28$ and $\mathrm{HH}-56$ achieved ultimate load deflections $5.25 \mathrm{~mm}$ and $4.65 \mathrm{~mm}$ respectively. On the contrary, specimens HW-28 and HW-56 exhibited deflections at ultimate load $4 \mathrm{~mm}$ and $4.4 \mathrm{~mm}$ respectively. At yield loads, the specimens cured with freshwater recorded deflections $0.65 \mathrm{~mm}$ and $0.77 \mathrm{~mm}$ for specimens HD-28 and HD-56 respectively. Specimens $\mathrm{HH}-28$ and $\mathrm{HH}-56$ achieved deflections $1.03 \mathrm{~mm}$ and $0.92 \mathrm{~mm}$ respectively. On the contrary, specimens HW-28 and HW-56 ex-

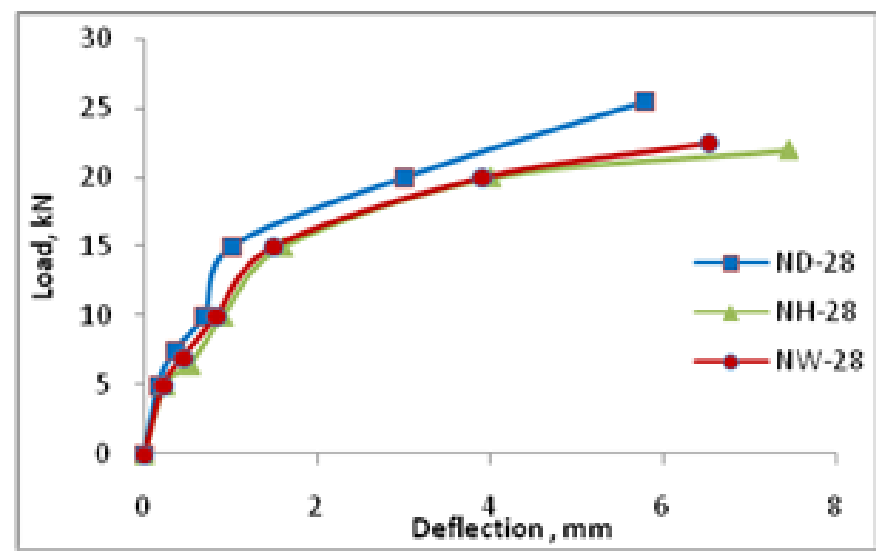

Figure 2: Load-deflection curve of NSC cured 28 days

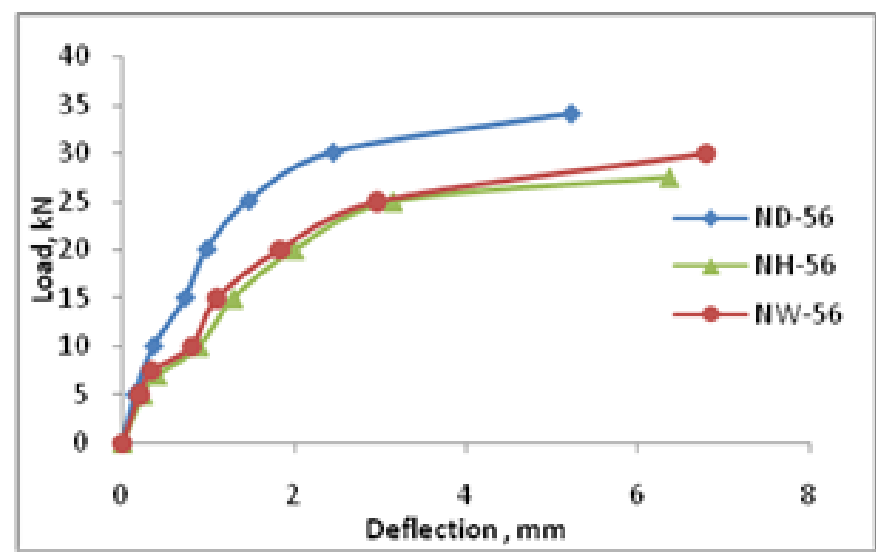

Figure 4: Load-deflection curve of NSC cured 56 days hibited deflections at ultimate load $0.81 \mathrm{~mm}$ and $0.89 \mathrm{~mm}$ respectively. The use of hospital waste water resulted in an increase in the first crack deflections $77.76 \%$ and $81.2 \%$ for the $\mathrm{HH}-28$ and $\mathrm{HH}-56$ specimens respectively. Also, in specimens cured in sewer waste water, the specimens recorded an increase in the first crack deflections 5.5\% and $31.2 \%$ for the HW-28 and HW-56 specimens respectively.

Table 6: Defection of tested slabs

\begin{tabular}{|c|c|c|c|}
\hline $\begin{array}{c}\text { Specimen } \\
\text { configuration }\end{array}$ & $\begin{array}{c}\text { Deflection } \\
\text { at first crack } \\
\text { load (mm) }\end{array}$ & $\begin{array}{c}\text { Deflection } \\
\text { at first yield } \\
\text { load (mm) }\end{array}$ & $\begin{array}{c}\text { Deflection } \\
\text { at first ulti- } \\
\text { mate load } \\
\text { (mm) }\end{array}$ \\
\hline ND-28 & 0.35 & 1.01 & 5.78 \\
\hline NH-28 & 0.53 & 1.22 & 7.44 \\
\hline NW-28 & 0.45 & 1.06 & 6.52 \\
\hline ND-56 & 0.36 & 1.47 & 5.22 \\
\hline NH-56 & 0.43 & 2 & 6.37 \\
\hline NW-56 & 0.39 & 2.27 & 6.8 \\
\hline HD-28 & 0.18 & 0.65 & 3.21 \\
\hline HH-28 & 0.32 & 1.03 & 5.25 \\
\hline HW-28 & 0.19 & 0.81 & 4 \\
\hline HD-56 & 0.16 & 0.77 & 2.89 \\
\hline HH-56 & 0.29 & 0.92 & 4.65 \\
\hline HW-56 & 0.21 & 0.89 & 4.4 \\
\hline
\end{tabular}

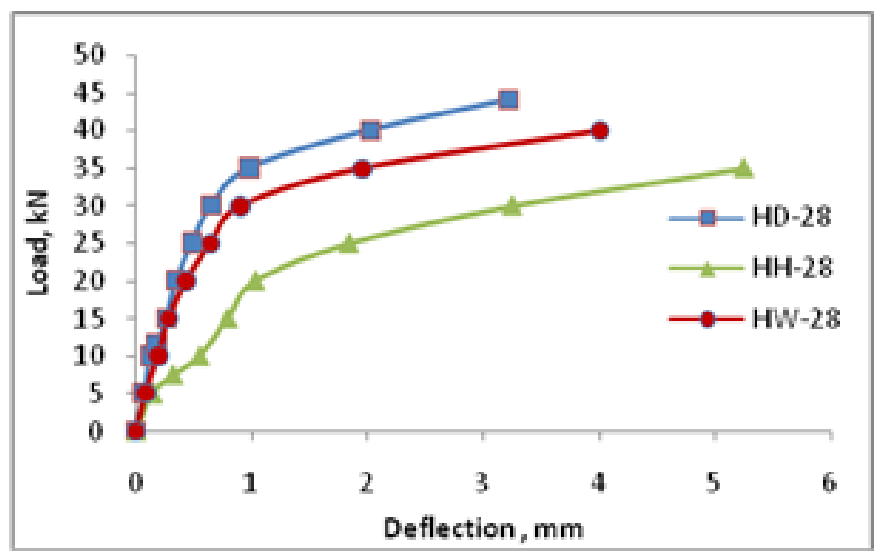

Figure 3: Load-deflection curve of HSC cured 28 days

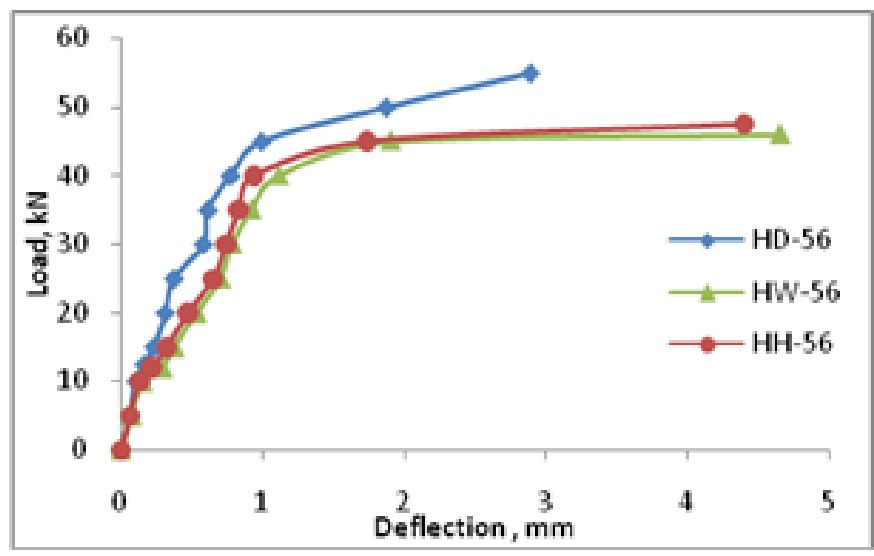

Figure 5: Load-deflection curve of HSC cured 56 days 


\section{Crack patterns}

The crack pattern was similar for all specimens. Howev$\mathrm{er}$, for high strength concrete specimens, the number and width of cracks were fewer, as shown in Figures (6) to (11). The cement and paste components combine with calcium, potassium, and sodium, so the hydroxides that dissolve in the acid media, and the carbon dioxide formed in this process, interact with the hydroxides then create brittle product contributes to reduce the ductility of failure in specimens cured with polluted waste water. In the specimens cured with sewer waste water and hospital waste water, there is a clear increase the number and width of cracks compared to the specimens cured with freshwater. In the specimens that were cured with sewer and hospital waste water for 56 days, it was observed that a number

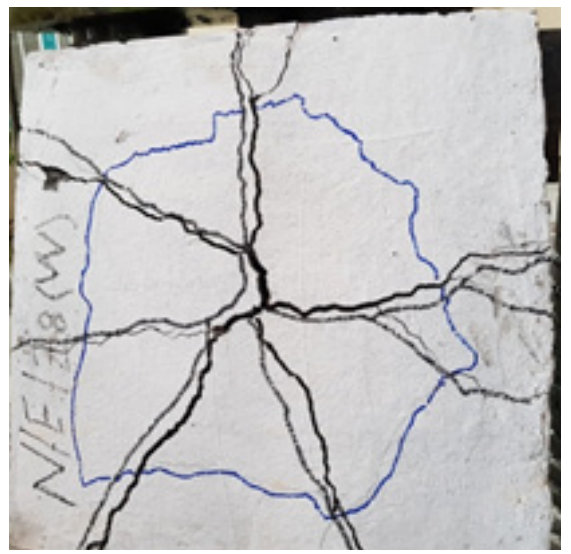

Figure 6: Failure pattern of ND-28

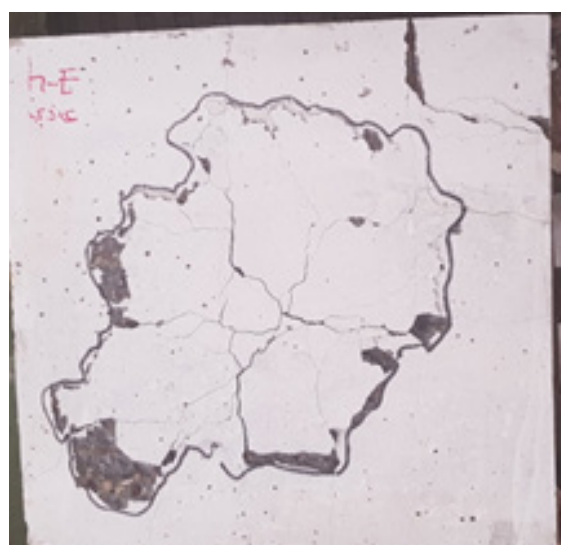

Figure 9: Failure pattern of HW-5

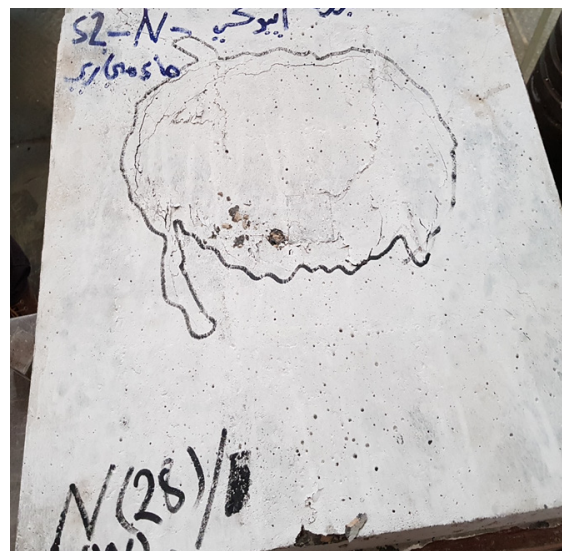

Figure 12: Failure pattern of $H D-56$ of cracks appeared more than their specimens that were cured with 28 days. Also, the cracks in these specimens are wider than the specimens cured for 28 days in polluted water. All tested specimens failed by punching shear, but the nature of failure is different in term of ductility, as it was noted that specimens cured with pure water where the failure type was ductile, unlike the specimens cured with hospital waste water and sewer waste water where failure was brittle. Additionally, the ductility of tested specimens were decreased when the submerging time in polluted water was increased for 56 days. It was found that the rapid dissolution resulting from the hydrochloric acid solution did not give sufficient time to start deterioration into the surfaces of the high strength concrete specimens, unlike the normal strength concrete specimens.

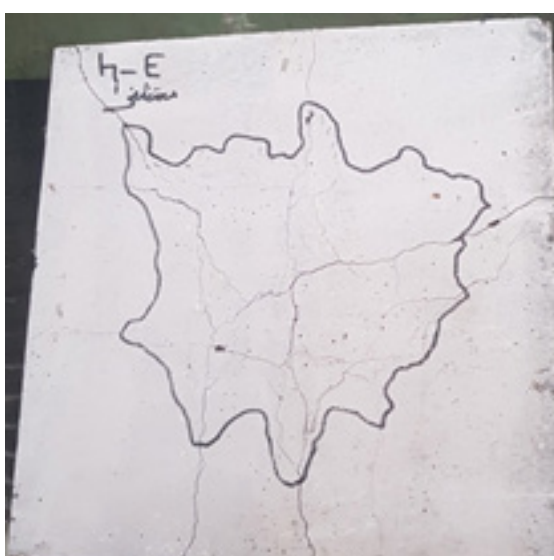

Figure 7: Failure pattern of $H D-28$

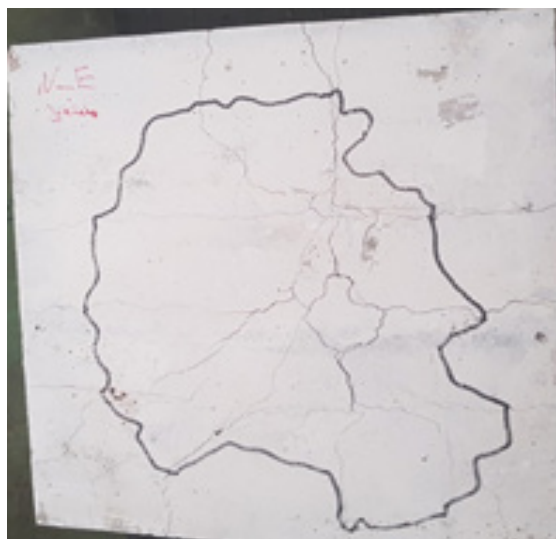

Figure 10: Failure pattern of $\mathrm{HH}-28$

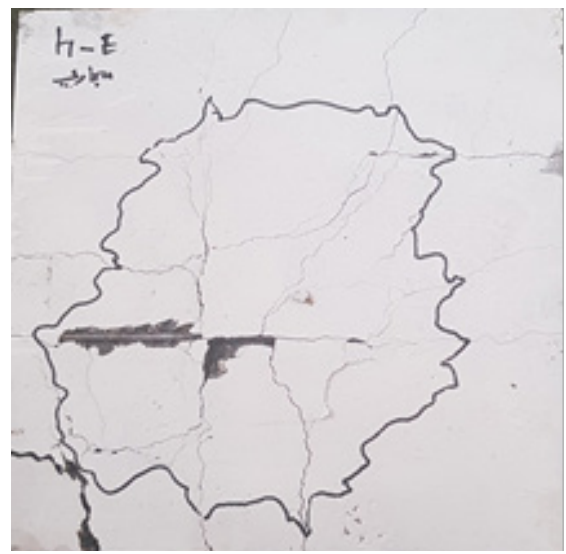

Figure 13: Failure pattern of NW-56

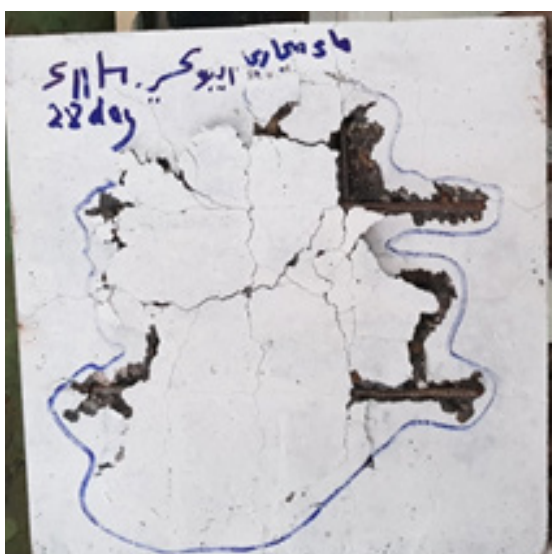

Figure 8: Failure pattern of $\mathrm{NH}-28$

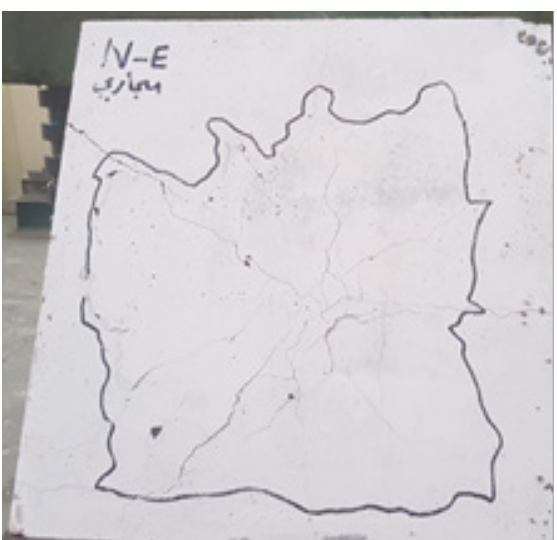

Figure 11: Failure pattern of HW-28

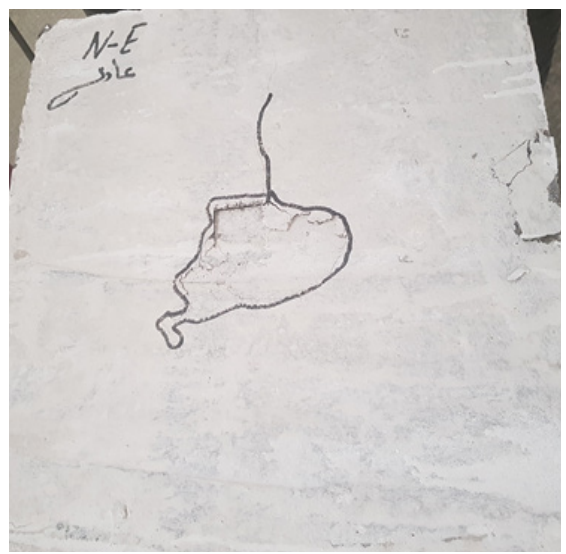

Figure 14: Failure pattern of $\mathrm{NH}-56$ 


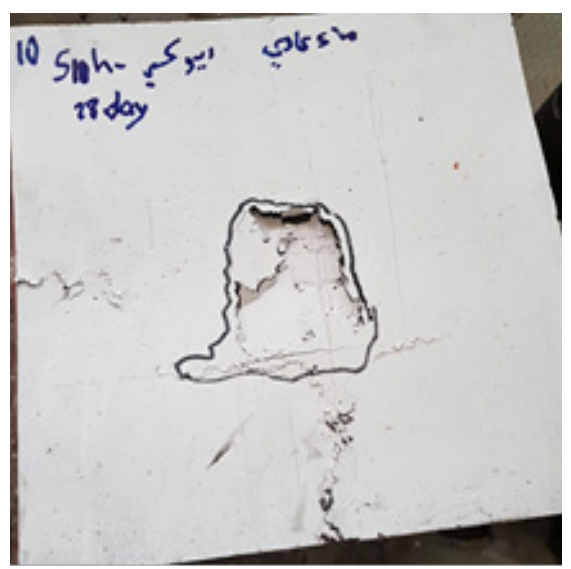

Figure 15: Failure pattern of ND-56

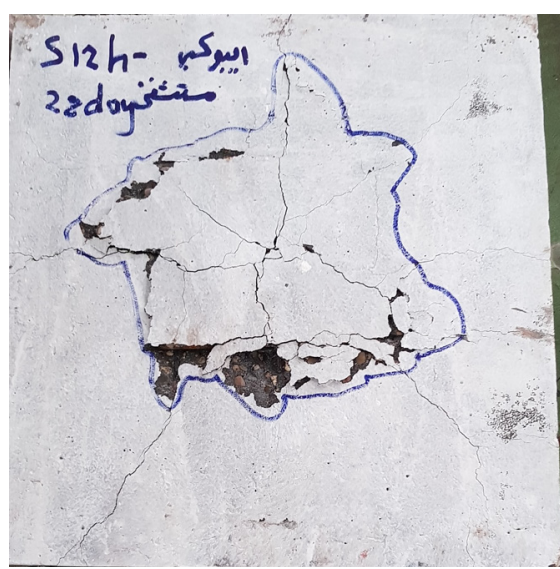

Figure 16: Failure pattern of $\mathrm{HH}-56$

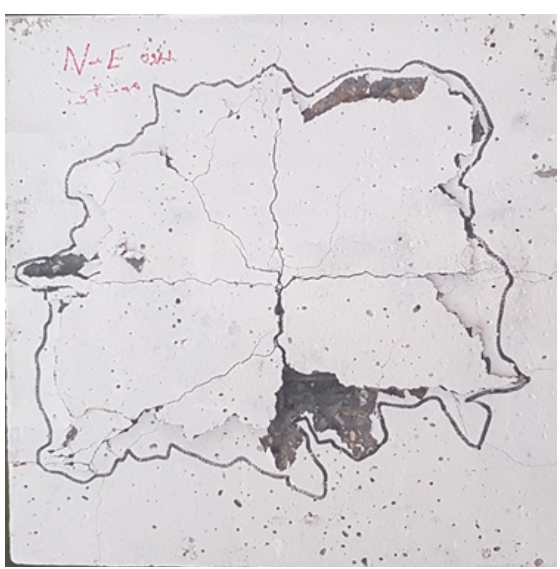

Figure 17: Failure pattern of NW-28

\section{Stiffness}

From Table (7), it can be said that the stiffness was a property of both type of curing water, and the concrete compressive strength. The stiffness decreases when immersion the slabs in hospital waste water and sewer waste water. The use of hospital waste water in curing the specimens decreased the stiffness of normal strength concrete specimens $\mathrm{NH}-28$ and $\mathrm{NH}-56$ by $33.1 \%$ and $33.6 \%$ respectively. For high strength concrete specimens cured with the hospital waste water $\mathrm{HH}-28$ and $\mathrm{HH}-56$, the decrease in slabs stiffness were $51.38 \%$ and $48 \%$ respectively, over the stiffness of freshwater cured slabs. Also, the specimens cured with sewer waste water recorded lower stiffness than specimens cured with freshwater. The decrease in stiffness for both normal strength concrete specimens NW-28 and NW-56 was $21.76 \%$ and $32.25 \%$ respectively. In the same trend, the stiffness of high strength concrete specimens HW-28 and HW-56 decreased by $27 \%$ and $43.3 \%$ respectively.

Table 7: Stiffness of tested slabs

\begin{tabular}{|c|c|c|}
\hline $\begin{array}{c}\text { Specimen } \\
\text { configuration }\end{array}$ & $\begin{array}{c}\text { Stiffness } \\
(\mathrm{kN} / \mathrm{mm})\end{array}$ & $\begin{array}{c}\text { Reduction in } \\
\text { stiffness }(\%)\end{array}$ \\
\hline ND-28 & 4.41 & $\mathrm{R}^{*}$ \\
\hline $\mathrm{NH}-28$ & 2.95 & 33.10 \\
\hline $\mathrm{NW}-28$ & 3.45 & 21.76 \\
\hline $\mathrm{ND}-56$ & 6.51 & $\mathrm{R}^{*}$ \\
\hline $\mathrm{NH}-56$ & 4.32 & 33.60 \\
\hline $\mathrm{NW}-56$ & 4.41 & 32.25 \\
\hline $\mathrm{HD}-28$ & 13.70 & $\mathrm{R}^{*}$ \\
\hline $\mathrm{HH}-28$ & 6.66 & 51.38 \\
\hline $\mathrm{HW}-28$ & 10 & 27 \\
\hline HD-56 & 19.03 & $\mathrm{R}^{*}$ \\
\hline HH-56 & 9.89 & 48 \\
\hline HW-56 & 10.79 & 43.30 \\
\hline${ }^{*}$ Reference specimens & \\
\hline
\end{tabular}

\section{CONCLUSIONS}

1. Presence of the specimens in hospital and sewer waste water for longer time contribute to decrease the ultimate strength, cracking strength, yielding load and stiffness.

2. The ultimate strength, cracking strength, yielding load and stiffness were decreased due to curing the specimens by hospital and sewer waste water.

3. The high strength concrete foundations appeared more resistance to the effect of hospital and sewer waste water.

4. The amount of deflections that occur in the specimens for the same loading value increased as a result of submerging the specimens with polluted water.

5. The compressive strength, modulus of elasticity and flexural strength of concrete is decreased due to curing of foundation specimens by hospital and sewer waste water.

\section{REFERENCES}

1. Mccormac, C. J and Brown, H. R., "Design of reinforced concrete 9 edition", USA, 2014, Published by Wiley \& Sons, Inc., Hoboken.

2. Mashhour, G., and Mahmoud, E., "Design of Reinforced Concrete Structures 2 edition", cario, 2007, AL-Balagh Publishing Company.

3. Federal Highway Administration (FHWA), Corrosion cost and preventive strategies in the United States, FHWA-RD-01-156, U.S. Dept. of Transportation, McLean, VA; 2002.

4. Andrade, C., Alonso, C. and Molina, F. J.," Cover cracking as a function of bar corrosion: part 1 - Experimental test", Materials and Structures, Vol.26, 1993, pp.453-464.

5. Ferreira, M., Montemo, M. and Simoes, A.," Chlorideinduced corrosion on reinforcing steel: From the fundamentals to the monitoring techniques", Cement Concrete Compos., Vol.25, No.4, 2003, pp.491-502. 
6. Apostolopoulos, C., "Mechanical behavior of concrete steel bars of monumental structures", Proceedings of the second Panhellenic conference on appropriate interventions for the safeguarding of monuments historical buildings, Thessaloniki, Greece, 2004.

7. Leung, K. Y., "Modeling of concrete cracking induced by steel expansion", Journal of Materials in Civil Engineering, May-June.

8. Allan, M. L., Cherry, B. W.," Factors controlling the amount of corrosion for cracking in reinforced concrete", Corrosion (Houston), Vol.48, No.5, 1992, pp. 426-430.

9. Bentur, A., and Jaegermann, C., "Effect of Curing in Hot Climate on the Development of the Properties of the Outer Skin of Concrete", Proceedings, FIP International Symposium, Jerusalem, Sept. 1988, pp. 4552.

10. Hou, J., Chung, D. D. L., "Effect of admixtures in concrete on the corrosion resistance of steel-reinforced concrete", Corrosion Science, 2000, Vol. 42, pp.1489-507.

11. Herrera, M. J., Torres-Acosta, A. A., Perez-Quiroz, J. T, Martinez, M.," Electrochemical evaluation of galvanized rebars in alkaline solutions with an inhibitor, In: Corrosion of infrastructure, chapter 3; Cementitious systems-monitoring, ECS transactions", The Electrochemical Society, Vol. 3, Issue 13. 2007. p. 139.
12. Alonso, C., Andrade, C., Rodriguez, J., and Diez, J. M., "Factors Controlling Cracking of Concrete Affected by Reinforcement Corrosion", RILEM, Materials and Structures, Vol. 31, Aug.-Sept. 1998, pp. 435441.

13. Hamad. B. S, Mike, J. A.," Experimental investigation of hot-dip galvanized reinforcement in normal and high strength concrete", ACI Structural Journal, Vol. 100, No.4, 2003, pp. 465-470.

14. Hamad, B. S, Jirsa, J. O., D’Abreu, N. I.,"Anchorage strength of epoxy coated hooked bars", ACI Structural Journal, Vol. 90, No.2, 1993, pp.210-217.

15. Jandin, G., Liao, H., Feng, Z. Q., and Coddet, C., "Correlations between operating conditions, microstructure and mechanical properties of twin wire arc sprayed steel Coatings", Mater. Sci. Eng., Vol. 349, A 2003, pp. 298-305. 